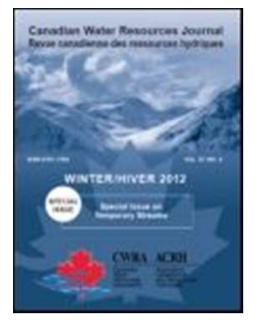

\title{
A review of simulated climate change impacts on groundwater resources in Eastern Canada.
}

\begin{tabular}{|r|l|}
\hline Journal: & Canadian Water Resources Journal \\
\hline Manuscript ID & TCWR-2017-0081.R2 \\
\hline Danuscript Type: & Original Paper \\
\hline Complete List of Authors: & $\begin{array}{l}\text { Larocque, Marie; UQAM, Sciences de la Terre et de l'atmosphère } \\
\text { Levison, Jana; University of Guelph, School of Engineering } \\
\text { Martin, Alexandre; UQA, Sciences de la Terre et de l'atmosphère } \\
\text { Chaumont, Diane; Ouranos Consortium, Climate scenarios }\end{array}$ \\
\hline Keywords: & Groundwater, Eastern Canada, Model, Climate change \\
\hline & \multicolumn{2}{|l}{} \\
\hline
\end{tabular}

SCHOLARONE"

Manuscripts 


\section{A review of simulated climate change impacts on groundwater}

2 resources in Eastern Canada

3

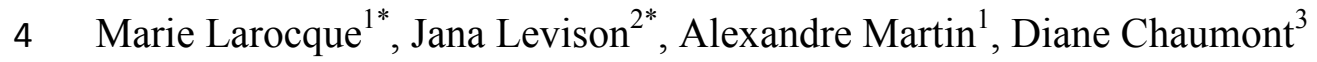

5

61 Département des sciences de la Terre et de l'atmosphère and GEOTOP Research

7 Center, UQAM, C.P. 8888 succ. Centre-ville, Montreal, QC, Canada, H3C 3P8, 514-

$8997-3000$ ext. 1515, larocque.marie@uqam.ca

92 School of Engineering and G360 Institute for Groundwater Research, University of

10 Guelph, 50 Stone Road E., Guelph, ON, N1G 2W1, jlevison@uoguelph.ca

113 Ouranos Consortium, 550 Sherbrooke West, $19^{\text {th }}$ floor, Montreal, QC, H3A 1B9,

12 Chaumont.Diane@ouranos.ca

13 


\section{Abstract}

15 In Eastern Canada, groundwater is the main water supply for most of the rural regions

16 and in many large urban communities. An understanding of the impacts of climate

17 change on this resource is crucial for sustainable water management in this region. The

18 objectives of this paper are to summarize the state of knowledge about possible climate

19 change impacts on groundwater dynamics in Eastern Canada thus providing a clearer

20 understanding of future conditions. Twenty-two studies are reviewed including Ontario,

21 Québec, New Brunswick, Nova Scotia, and Prince Edward Island, to identify the impacts

22 on groundwater recharge and river baseflows. The studies disagree in their estimates of

23 changes in future recharge conditions, and no trend from West to East was revealed. This

24 could be due to the use of different modelling approaches (model type, climate change

25 scenario, future horizon). Nonetheless, more inter-annual variability during the summer

26 and earlier snowmelt periods causing seasonal shifts in the recharge cycle are expected.

27 This review provided new insights that lead to the following recommendations for future

28 studies: 1) use a variety of climate models and emission scenarios; 2) promote the use of

29 integrated models when possible; 3) study long-term climate change impacts on

30 groundwater resources at different scales; 4) simulate the combined effects of climate

31 change and other pressures; and 5) develop models that cover other regions of Eastern

32 Canada as dictated by stakeholders and water managers.

34 Key words: Groundwater, Eastern Canada, Model, Climate change 


\section{Résumé}

37 Dans l'est du Canada, l'eau souterraine est la principale source d'approvisionnement en 38 eau en région rurale et dans plusieurs grandes villes. La compréhension des impacts des

39 changements climatiques sur cette ressource est cruciale pour la gestion durable de l'eau

40 dans cette région. Les objectifs de cette revue étaient d'établir l'état des connaissances

41 sur les impacts possibles des changements climatiques sur la dynamique des eaux

42 souterraines dans l'est du Canada afin de mieux appréhender les conditions futures.

43 Vingt-deux études portant sur les provinces de l'Ontario, du Québec, du Nouveau-

44 Brunswick, de la Nouvelle-Écosse et de l'Ile-du-Prince-Édouard ont été analysées pour

45 déterminer les impacts sur la recharge des eaux souterraines et les débits de base des

46 cours d'eau. Les études ne s'entendent pas sur une l'évolution future de la recharge et

47 aucune tendance de l'ouest vers l'est n'a été mise en évidence. Ceci pourrait être causé

48 par les différentes approches de modélisation utilisées (type de modèle, scénario

49 climatique, horizon futur). Néanmoins, les résultats montrent généralement une plus

50 grande variabilité interannuelle de la recharge estivale et une recharge printanière plus

51 hâtive. Les études montrent que les débits d'étiage pourraient diminuer, ce qui induirait

52 des conditions critiques pour les approvisionnements en eau et pour les écosystèmes.

53 Cette revue a fourni un nouvel éclairage qui a conduit aux recommandations suivantes

54 pour les études futures: 1) utiliser une variété de modèles climatiques et de scénarios

55 d'émission; 2) utiliser des modèles intégrés lorsque possible; 3 ) étudier les impacts à long

56 terme des changements climatiques sur les ressources en eaux souterraines à différentes

57 échelles; 4) simuler les effets combinés du changement climatique et d'autres pressions; 
58 et 5) élaborer des modèles qui couvrent d'autres régions de l'est du Canada dictées par les

59 intervenants et les gestionnaires de l'eau.

60

61 Most-clés: eau souterraine, est du Canada, modèle, changement climatique

62

63 


\section{INTRODUCTION}

65 Throughout the world, climate change has become evident from the observations of

66 global mean temperature rise and the higher frequency of extreme weather events (IPCC

67 2013). These changes could affect groundwater resources in a variety of ways (Taylor et

68 al. 2012). In a warmer climate, increasing demand of water is expected to lead to

69 increased pumping rates for drinking water and irrigation. Conditions of depleting

70 groundwater reservoirs and reduced groundwater flow to rivers, wetlands, and lakes are

71 either already clearly evident or expected around the world in the next decades (Ferguson

72 and Gleeson 2012; Crosbie et al. 2013; Castle et al. 2014; Döll et al. 2014; Kløve et al.

73 2014; de Graaf et al. 2017).

74 Canada is amongst the world's richest countries in terms of fresh water resources

75 (FAO 2003). Throughout Canada, groundwater provides approximately 30\% of the

76 population with potable water and is often the only source of water in rural areas (ECCC

77 2017). When investigating the presence of climate change impacts in past time series of

78 baseflows and groundwater levels across the country, Rivard et al. (2009) have identified

79 mixed increasing and decreasing trends country-wide. However, the Atlantic Provinces

80 showed statistically significant decreases of baseflows, while some regions north of $55^{\circ} \mathrm{N}$

81 had increasing baseflows. The majority of the longer time series showed negative trends

82 during the summer months. Chen (2015) assessed the impact of climate change on

83 groundwater dynamics at the continental-scale using the integrated HydroGeoSphere

84 model (Therrien et al. 2010) for the entire country and the northern part of the United-

85 States. Confirming some of the trends identified by Rivard et al. (2009), Chen (2015) 
86 showed that annual streamflow in most of the northern main rivers could increase under

87 climate change, but results for the southern regions were less clear.

88 In 2016, more than $68 \%$ of the country's population resided in Eastern Canada, 89 notably in Ontario and Québec (Statistics Canada 2016). In Eastern Canada, groundwater 90 is a frequent source of water for many usages like municipal water supply, irrigation for 91 agriculture, and private wells for potable water. In Ontario, Québec, and the Atlantic 92 Provinces respectively, 14,17 , and $12 \%$ of irrigation water for farming was taken from 93 groundwater in 2012 (Statistics Canada 2012). A rainfall rate increase is expected, based 94 on a high-resolution regional climate modelling study over the Great Lakes basin 95 (d'Orgeville et al. 2014). Among other effects, climate change is expected to lead to 96 earlier spring flood events and to more severe summer low flows (Ouranos 2015). In the 97 Atlantic Provinces, more storm events and increasing storm intensity, rising sea levels, 98 storm surges, and coastal erosion are expected from climate change (Climate Action 99 Network 2017). The impacts of climate change on groundwater resources are not fully 100 understood and a global picture of possible future conditions is not yet available for water 101 managers.

102 The simulation of possible groundwater flow conditions provides interesting outlooks 103 for potential conditions in future decades. However, modeling studies are expensive, are 104 often of local application, and can be based on a wide array of future conditions (e.g., 105 stemming from different climate models, groundwater flow models, and emissions 106 scenarios). Holman et al. (2011) made methodological recommendations aimed at 107 improving the assessment of climate change impacts on groundwater. In recent years, the 108 general approach has tended towards implementing these recommendations. As a result, 
109 recent studies now commonly used multiple climate change scenarios, including 110 scenarios from global climate models (GCMs), regional climate models (RCMs), 111 different greenhouse gas (GHG) emission scenarios, different downscaling methods and 112 different future horizons (see discussion in Kurylyk and MacQuarrie 2013). Additionally, 113 modeling studies are performed on a wide variety of spatial scales, using models that 114 simulate the dynamics of the entire water cycle or fluxes in some reservoirs only (soil, 115 aquifer, or river). For all these reasons, it is difficult to compare modeling results and to 116 use them in water management decisions that would include adaptation options. The 117 objective of this paper was to summarize the state of knowledge about simulated climate 118 change impacts on groundwater dynamics in Eastern Canada, in order to provide a clearer 119 understanding of possible future conditions and to make recommendations for future 120 studies.

\section{BACKGROUND INFORMATION}

\section{Hydrological, hydrogeological, and integrated models}

124 A wide array of models are available to study issues related to groundwater flow. 125 Models such as the spatially distributed HYDROTEL model (Fortin et al. 2001) or the 126 conceptual HBV model (Lindström et al. 2007), can be used to simulate surface flow 127 processes. They usually include a highly simplified representation of the aquifer that 128 empties with a calibrated reservoir coefficient. Nevertheless, surface flow models can be 129 useful to study climate change impacts on groundwater resources if they are used to 130 provide information on future base flow which corresponds to groundwater discharge to 131 the surface in rivers. 
132 Groundwater flow models such as MODFLOW (saturated flow; Harbaugh 2005) and 133 FEFLOW (saturated and unsaturated flow; DHI-WASY 2013) are widely used. This 134 category also includes models dedicated to simulate recharge and which are used with 135 groundwater flow models to provide the upper boundary condition of water that reaches 136 the aquifer through the surface. The most widely used in this category is the HELP model 137 (Schroeder et al. 1994). The SUTRA model (Voss and Provost 2002) allows the 138 simulation of coupled groundwater flow and groundwater temperature and is used to 139 understand the warming effect of climate change on groundwater flow systems. The 140 SEAWAT model (Guo and Langevin 2002) is software based on MODFLOW/MT3DMS 141 (Bedekar et al. 2016). It simulates 3D density-dependent groundwater flow and is 142 frequently used to simulate saltwater intrusion in coastal aquifers.

143 Integrated models represent the entire land water cycle and usually include 144 evapotranspiration, snow accumulation and melting, runoff, water routing at the surface 145 and in the river channel, infiltration, groundwater flow and groundwater discharge to 146 surface reservoirs. HydroGeoShere (Therrien et al. 2010), MikeSHE (DHI Software 147 2007), and CATHY (Camporese et al. 2010) are three examples of integrated models that 148 are widely reported in the scientific literature.

\section{Emission scenarios, climate models, and projected horizons}

151 Earlier climate modeling studies were based on GHG emission scenarios. IPCC (2000) 152 recommended the use of different emission scenarios to be used in climate modeling 153 studies (A1, A2, B1 and B2, including sub-scenarios). Representative Concentration 154 Pathways (RCPs) including four GHG concentration trajectories are now used to replace 
155 the former emission scenarios in climate modeling and research (van Vuuren et al. 2011).

156 The RCPs describe potential futures of the main drivers of climate change: greenhouse

157 gas and air pollutant emissions. The scenarios are named based on the change in radiative

158 forcing in 2100 compared to pre-industrial values. The RCP4.5 scenario (optimistic)

159 represents an increase in radiative forcing of $4.5 \mathrm{~W} / \mathrm{m}^{2}$ relative to pre-industrial values. It

160 is associated with a capping of emissions which would stabilize the radiative forcing

161 caused by climate change in 2100. The RCP8.5 scenario (pessimistic) represents no

162 change in current human behaviour. Emissions continue to rise beyond 2100 when the

163 radiative forcing is increased by $8.5 \mathrm{~W} / \mathrm{m}^{2}$ relative to pre-industrial values. Most of the

164 recent climate change impact studies use these two RCPs to account for GHG 165 concentration scenarios.

166 Climate projections are generated either directly from GCMs or from RCMs driven by

167 GCMs. The shift from SRES to RCPs also corresponds to the replacement of the CMIP3

168 global climate model ensemble (Meehl et al. 2007) with the CMIP5 ensemble (Taylor et

169 al. 2012). There are currently 20 GCMs and 12 pairs of RCM-GCM combinations for

170 North America operated by different research groups around the world for which climate

171 projections are available. Using multiple climate scenarios combining climate models and

172 emission scenarios is the usual approach for climate change impact studies to provide an

173 array of possible futures.

174 Data from climate models that are readily available for use in hydrological and 175 hydrogeological models are air temperature (daily minimum, maximum or average) and 176 precipitation. These data are generated on grids of various sizes, depending on the 177 climate model used to simulate them. Because the hydrological and hydrogeological 
178 models are usually of more local scale than the climate models' resolution, and their 179 outputs usually include statistical bias, the climate model outputs are often adjusted using 180 post-processing methods. When using statistical downscaling (Themeß1 et al. 2010; 181 Teutschbein and Seibert, 2012), climatic variables are linked to local meteorological 182 variables using different methods (e.g., quantile mapping, linear regression, analog 183 method). This method takes into consideration changes in climate variability. The delta 184 change method (Diaz-Neto and Wilby 2005) calculates mean deviations in temperature 185 and precipitation between future and past periods. It can be used on monthly or daily 186 data. This method assumes that rainfall frequency is not modified with climate change. 187 Dynamical downscaling (Giorgi and Mearns 1991) corresponds to running a fine scale 188 regional climate model on a sub-domain driven at its boundary by a global climate 189 model. Results from these models sometimes still need to be post-processed.

190 The earliest studies of climate change impacts on groundwater resources used climate 191 scenarios for 30 to 40 years over which the future conditions were to be considered 192 constant, and compared to simulated recent climate. The more recent climate impact 193 studies use continuous scenarios in which the simulated future conditions evolve through 194 time from past conditions in the 1950 s to future 2100 conditions.

\section{STUDIED REGIONS}

197 The surveyed literature concerns studies that simulate future groundwater flow 198 conditions for the provinces of Ontario, Québec, New Brunswick, Nova Scotia, and 199 Prince Edward Island. Newfoundland and Labrador was not included in this overview 200 because no provincial- nor local-scale studies were available. Only peer-reviewed studies 201 in journal papers and theses reporting the use of groundwater flow models, integrated 
202 surface-groundwater flow models, recharge models, as well as surface flow models 203 which include at least a simple representation of aquifers and a quantification of 204 baseflows were considered. Surface flow studies with little or no representation of 205 groundwater reservoirs or without any explicit quantification of recharge or groundwater 206 contributions to rivers were excluded. A total of 22 studies have thus been summarized 207 spanning a wide region between southern Ontario and the Magdalen Islands (QC) 208 (Figure 1).

\section{Ontario-based studies}

211 Six studies focusing on groundwater resources and climate change have been reported 212 in the literature for Ontario (see Table 1 and Figure 1b). The studies have been conducted 213 only in southwestern Ontario with no models applied to eastern or northern Ontario. 214 Various hydrological modelling approaches, from strictly recharge models (HELP), to 215 fully-integrated models (e.g., HydroGeoSphere (HGS) and MikeSHE) have been 216 employed. Most of the studies were based on data from multiple climate models. The 217 emission scenarios included $\mathrm{A} 2, \mathrm{~B} 2$, and a doubled $\mathrm{CO}_{2}$ equilibrium (prior to the IPCC 218 (2000) Special Report Emission Scenarios). Projected simulated durations ranged from 21920 years (Sultana and Coulibaly 2011) to 60 years (Brouwers 2007). The earliest future 220 horizon starts in 2020 (Brouwers 2007), and the latest ends in 2080. Some studies 221 projected a future time span without using specific years (40 years in Jyrkama and Sykes 2222007 and Colautti 2010). McLaren and Sudicky (1993) projected their future steady-state 223 flow conditions in 2050 (no time-span).

224 One of the most studied aquifer systems in Canada regarding climate change impacts 225 on groundwater at the regional-scale is the Grand River watershed $\left(6,800 \mathrm{~km}^{2}\right)$ in 
226 southern Ontario. As early as the 1990s, researchers were anticipating the potential

227 impacts of the climate change on its groundwater resources. For instance, McLaren and

228 Sudicky (1993) used a 2D, steady-state groundwater flow model for a subregion of the

229 Grand River watershed to examine predicted head and baseflow changes. In the 230 groundwater model, a recharge change of -15 to $-35 \%$ lead to baseflow changes of -17 to $231-39 \%$.

232 Jyrkama and Sykes (2007) presented a physically-based method to evaluate temporal

233 and spatial variability of climate change impacts on the recharge over the Grand River 234 watershed $\left(6,800 \mathrm{~km}^{2}\right)$. They used a GIS version of the HELP model, a distributed water 235 balance and routing model using a pseudo-2D representation to simulate the recharge. 236 Combining scenarios for temperature, precipitation and solar radiation changes yielded $237+10 \%$ to $+53 \%$ for future groundwater recharge, $-12 \%$ to $+10 \%$ for future surface runoff, $238+3 \%$ to $+12 \%$ for future evapotranspiration. Among various conclusions for the Grand 239 River watershed, the authors outlined that the increased recharge projected for the future 240 would not be uniformly distributed. Moreover, impacts were controlled by local 241 groundwater elevations, types of soil and land uses.

242 Brouwers (2007) coupled the HELP model with the HydroSphere model (precursor of 243 the HGS model) for saturated groundwater flow to simulate the projected behaviour of 244 the Alder Creek basin $\left(80 \mathrm{~km}^{2}\right)$, a subwatershed of the Grand River. The simulations 245 showed a shift in the snowmelt timing, causing a general reduction of the runoff, an 246 increase of the evapotranspiration (mainly during the summer months), and a general 247 increase of the infiltration. Impacts on groundwater were generally lower than on surface 248 water. Changes in average monthly recharge ranged from $+0.36 \mathrm{~mm}$ (urban land, 2040- 
2492060 ) to $+4.12 \mathrm{~mm}$ (agricultural land, 2060-2080). The author reports that recharge 250 increased the most during the spring, with a shift of the melting season towards earlier 251 dates, although this is not apparent from the average monthly values.

252 Colautti (2010) applied the integrated HGS model in the Grand River watershed $253\left(6,800 \mathrm{~km}^{2}\right)$ using five climate scenarios. Future scenarios were constructed based on 254 modifying the 1960-1999 historical precipitation record (by $-5 \%,+5 \%,+10 \%,+15 \%$, $255+20 \%$ ), bounded by GCM-based climate scenario ranges. These scenarios yielded 256 recharge changes of $-5 \%$ to $+22 \%$, and river discharges changes of $-15 \%$ to $+59 \%$ with 257 changes in groundwater levels between $-0.55 \mathrm{~m}$ and $+1.25 \mathrm{~m}$. At the local-scale, Colautti 258 (2010) highlighted that simulated depth below ground surface to water table responded 259 differently from one zone to another, suggesting that the local flow patterns may be more 260 sensitive to future climate changes.

261 Sultana and Coulibaly (2011) used the integrated MikeSHE model for the evaluation 262 of climate change impacts on the Spencer Creek watershed $\left(291 \mathrm{~km}^{2}\right)$ in southern Ontario 263 The simulations predicted a change of annual groundwater recharge between $-6 \%$ and $2640.5 \%$. This decrease was particularly visible during summer and fall seasons. The authors 265 did not quantify the change in river baseflow, but they note that it is expected to decrease 266 due to the reduction of recharge.

267 Recently, Motiee and McBean (2017) applied HELP in the Guelph region (unspecified 268 study area) of the Grand River watershed to investigate the impacts of climate change on 269 recharge. The authors predicted increased evaporation and decreased summer recharge, 270 with increased recharge in the winter months due to changing freeze/thaw dynamics. 271 They determined a future recharge change between $+7 \%$ and $+12 \%$. 


\section{Quebec-based studies}

274 Ten local to regional-scale climate change and groundwater studies in the province of

275 Québec have been reported in the literature (see Table 2 and Figure 1c). The models used 276 a surface flow (HYDROTEL), a groundwater flow (MODFLOW), or integrated surface277 groundwater flow (CATHY, HGS, and MikeSHE). All the studies were based on data 278 from multiple climate models. Simulated future time periods are all similar in lengths, 279 ranging between 24 years (Sulis et al. 2012) and 32 years (Sulis et al. 2011), with 280 projected horizons starting as early as 2010 (2010-2039; Quilbé et al. 2008) and as late as 2812071 (2071-2100; Cochand 2014). The latest end for future horizons was 2100 (Cochand 282 2014). The Québec-based study from Lemieux et al. (2015) in the Magdalen Islands is 283 discussed in the Atlantic studies because of their geographical proximity.

284 Quilbé et al. (2008) assessed the effect of climate change on the Chaudière River 285 watershed $\left(6,682 \mathrm{~km}^{2}\right)$, with the HYDROTEL model. The results that are of interest for 286 the current paper concern the critical streamflow sequences over seven days and return 287 periods of two and ten years $\left(\mathrm{Q}_{2-7}\right.$ and $\left.\mathrm{Q}_{10-7}\right)$, as well as critical streamflow sequences 288 over 30 days for five years return periods $\left(\mathrm{Q}_{5-30}\right)$, which are considered to represent river 289 baseflows during the summer period. Interestingly, the scenarios performed with the 290 Delta method showed changes in the critical low flows of $-23 \%$ to $-5 \%$ for the $\mathrm{Q}_{2-7},-25 \%$ 291 to $-7 \%$ for the $\mathrm{Q}_{10-7}$, and $-29 \%$ to $-7 \%$ for the $\mathrm{Q}_{5-30}$. The simulations performed with 292 statistical downscaling showed no obvious effect of climate change on summer low 293 flows. 
294 Sulis et al. (2011) evaluated the climate change impacts on the Anglais River 295 (690 km²; Montérégie region) with the integrated CATHY model. The authors identified 296 that the impacts on the river flow at the outlet were greater during winter peaks and 297 summer droughts. In future conditions, the total recharge changed by $+16 \%$; however, the 298 changes throughout the year were not constant. The winter recharge was higher $(+49 \%)$ 299 due to increased rain and snowmelt, the spring recharge remained the same, and the 300 summer recharge was lower $(-8 \%)$ due to increased evapotranspiration. The fall recharge 301 was higher $(+22 \%)$ due to increased precipitation. A spatial analysis of recharge patterns 302 shows that the greatest variations in recharge are expected to occur at the highest 303 elevations. The future simulated river flows at the outlet during the June, July, and 304 August summer months (considered as baseflows) were 56\% lower than those of the 305 reference period.

306 In the same des Anglais watershed, Sulis et al. (2012) also investigated the impact of 307 climate change uncertainty in hydrological processes using the CATHY model. 308 Hydrological responses (streamflow, recharge and groundwater storage) reacted 309 differently to the precipitation and temperature variations between the climate models. 310 River discharge changes varied from $-18 \%$ to $+11 \%$. For the future climate, the low flow 311 occurrence frequency increased for all simulations, with a percentage change in low flow 312 occurrence between $+12 \%$ and $25 \%$ for the members (comparison based on the 313 percentage of days with a discharge lower than the first decile of present-day discharges).

314 The change in total recharge varied between a $-15 \%$ and $+4 \%$. The authors underline the 315 impact of changing sequences of rainy days on groundwater recharge. 
316 Bourgault et al. (2014) simulated aquifer-peatland-river interactions under climate 317 change in the Lanoraie peatland complex $\left(364 \mathrm{~km}^{2}\right)$. The authors used MikeSHE and 318 activated only its groundwater flow component. From three climate scenarios, the 319 recharge was estimated using a simple water budget calculation, based on the hypothesis 320 that there is no runoff on the highly permeable sand aquifer. The resulting recharge 321 variations ranged between $0 \%$ and $-50 \%$. The authors used average recharge scenarios of $322-50 \%$ and $-20 \%$ to simulate groundwater flow. It appeared that the storage capacity of the 323 organic deposits contributed to prevent drastic drawdown to the surrounding aquifers and 324 limit river baseflow decreases. However, despite the mitigating role of the peatland, the 325 climate scenarios indicated a change in river baseflows between $-41 \%$ and $-16 \%$.

326 Cochand (2014) simulated the impact of climate change on the Saint-Charles River 327 watershed $\left(553 \mathrm{~km}^{2}\right)$ using the integrated HGS model. The summer and fall low flows 328 (June to October) changed between $-25 \%$ and $-10 \%$, mainly due to increased 329 evapotranspiration. Increasing temperatures in winter and early snowmelts triggered 330 recharge increases $(+150$ to $+300 \%)$ between December and March and recharge 331 decreased (-50\%) in April-May. Recharge decreased also between June and October, but 332 less markedly ( -4 to $-8 \%)$. The winter recharge increase was observed in the higher 333 topography areas.

334 Levison et al. (2014a) developed a groundwater flow model for the Covey Hill Natural 335 Laboratory in southern Québec $\left(173 \mathrm{~km}^{2}\right.$; Montérégie region) using a steady-state 336 groundwater flow model (MODFLOW). Similarly to Bourgault et al. (2014), the authors 337 compared the net precipitation from the future horizon to that of the reference period for 338 all the members, with changes in net precipitation ranging between $-30 \%$ and $+10 \%$. 
339 Assuming that recharge variations should be similar to the net precipitation variations, 340 they imposed recharge change scenarios of $-30 \%,-15 \%$ and $+10 \%$, The total 341 contribution from the aquifer to the rivers and streams over the study area varied between $342-44 \%$ and $+14 \%$ for the $+10 \%$ and $-30 \%$ recharge scenarios respectively. Near the 343 peatland, the direction of hydraulic gradients also changed in the future conditions, 344 making the peatland feed the aquifer during the summer, the fall and the winter seasons.

345 In the same location, Levison et al. (2014b) simulated the dynamics of small bedrock 346 springs under climate change conditions using the HGS model representing local scale 347 discrete fractures. Levison et al. (2014b) applied 10 climate change scenarios directly to 348 the HGS model instead of using a sensitivity analysis approach and imposed net 349 precipitation at the soil surface. The simulated spring flow rates changed by +5 to $+6 \%$ 350 under future conditions, depending on the spring elevation. Results also indicated a 351 significant increase in the number of days of spring flow activity $(+1$ to $+2 \%)$ and 352 generally more variability in the duration of the flow for all springs, although these 353 increases varied considerably depending on the spring location. The authors proposed 354 that this location might be resilient enough to face the projected climate changes, but 355 emphasized the importance of improving follow-up programs on ecologically sensitive 356 sites to acquire more information about the ability of natural habitat to face different 357 climate conditions.

358 With the Hydroclimatic Atlas, the CEHQ (2015) synthesized the impact of climate 359 change on the river regime of 50 medium size basins (500 to $20000 \mathrm{~km}^{2}$ ) in southern 360 Québec. The HYDROTEL model was used to simulate flows. Changes in a series of 361 indicators were quantified to assess the impact of climate change on the watershed 
362 hydrology. The indicators of interest here are those for summer low flows which are 363 associated with baseflows. The results showed that summer low flows events will 364 generally be more severe and longer for all scenarios and all watersheds: $\mathrm{Q}_{2-7}$ changed by $365-54 \%$ to $-6 \%, Q_{10-7}$ changed by $-63 \%$ to $-9 \%$, and $\mathrm{Q}_{5-30}$ changed by $-56 \%$ to $-8 \%$.

366 Levison et al. (2016) also investigated long-term trends in groundwater recharge and 367 discharge for the Covey Hill Natural Laboratory using the MODFLOW model. The 368 authors compared the simulated responses of the groundwater system using observed and 369 simulated data from 1900 to 2010 and also used projected climate data for 2041-2070.

370 They used the Levison et al. (2014a) calibrated model, but applied the 10 RCM climate 371 change scenarios from Levison et al. (2014b). It was assumed that recharge variations 372 should be similar to the net precipitation variations $(-4 \%$ to $+15 \%)$. For the future 373 scenarios, average baseflows for the three rivers increased (from $+10 \%$ to $+14 \%$ ), and 374 average spring flow also increased $(+18 \%)$. These results, in comparison to Levison et al. $375(2014 \mathrm{a} ; 2014 \mathrm{~b})$ illustrate the complexity and uncertainty for making predictions for 376 groundwater and climate change.

\section{$378 \quad$ Atlantic Canada studies}

379 Thus far in the literature, six climate change related groundwater modelling studies 380 have been reported for New Brunswick, Nova Scotia, and Prince Edward Island. 381 Although it is located in the Province of Québec, the Lemieux et al. (2015) study in the 382 Magdalen Islands is reported here because of its geographical proximity. The models 383 simulate recharge (HELP), groundwater flow and water temperature (SUTRA), 384 unsaturated-saturated groundwater flow (FEFLOW), and salt water intrusion 
385 (SEAWAT). The emission scenarios are A1B, A2, B1, and B2. The future model runs 386 span 27 years (Lemieux et al. 2015) to 90 years (Green and MacQuarrie 2014). The 387 future horizons start as early as 2011 and end as late as 2100 (both from Green and 388 MacQuarrie 2014) (see Table 3 and Figure 1d).

389 Hansen (2012) used the SEAWAT model to estimate submarine groundwater 390 discharge under climate change conditions on the coastal aquifer of Summerside (PEI). 391 The authors simulated a combination of changes in recharge (assumed to be the same as 392 changes in precipitation), changes in sea water levels and changes in aquifer pumping 393 rates. Their results show that climate change has limited impact coastal groundwater 394 discharge in the study area. Sea-level rise leads to significant saltwater intrusion (between 39530 and $60 \mathrm{~m}$ ) but is mitigated by a +5 to $+8 \%$ change in recharge. Increasing groundwater 396 pumping appears to be the dominant process for saltwater intrusion.

397 Kurylyk and MacQuarrie (2013) simulated the impacts of climate scenarios on the 398 recharge with the HELP model at the local-scale watershed, on the Otter Brook 399 watershed (NB) $\left(9.5 \mathrm{~km}^{2}\right)$. The annual recharge changes varied between $-6 \%$ and $+58 \%$. 400 The authors show that the post-processing method had a large impact on the results, 401 sometimes a larger impact than the emission scenario.

402 Kurylyk et al. (2014) applied the seven recharge scenarios developed by Kurylyk and 403 MacQuarrie (2013) to simulate groundwater discharge to streams in the unconfined 404 granular aquifer of Otter Brook (NB) under climate change. Groundwater flow, freezing, 405 and thawing were simulated with the SUTRA model, for two aquifer configurations 406 (aquifer discharge to the brook or to lateral seeps). The summer groundwater discharge 407 rates varied between $-6 \%$ and $+39 \%$, with an increase of discharging water temperature 
408 up to $3.6^{\circ} \mathrm{C}$. The authors conclude that small and shallow aquifers are susceptible to air 409 temperature increases and that thermal refugia could be impacted through warmer 410 groundwater inflows.

411 In the Richibucto region of New Brunswick, Green and MacQuarrie (2014) used the 412 SEAWAT and HELP models to examine relative impacts of climate change-induced 413 variations in recharge, sea level rise and increased groundwater extraction on saltwater 414 intrusion (2011-2100). Two recharge scenarios were based on a previous study (using the 415 HELP model; Jacobs 2011): one scenario reflected the projected changes developed by 416 Jacobs (2011), and the second doubled the percent change of those projections relative to 417 historic conditions. Recharge changed between $-27 \%$ and $-5 \%$. The impact of decreasing 418 recharge was the most important at depths less than $60 \mathrm{~m}$ below sea level. Interestingly, 419 sea-level rise had the least important effect on seawater intrusion in shallow to 420 intermediate aquifers for the future scenarios. Because of the importance of both recharge 421 and pumping on seawater intrusion, the authors suggested that actions to control land use 422 influencing recharge, as well as pumping rates, may help to protect coastal fresh423 groundwater supplies.

424 Rivard et al. (2014) investigated the impacts of climate change on the HELP-simulated 425 recharge for the Annapolis Valley (NS) $\left(546 \mathrm{~km}^{2}\right)$. The results showed a change in 426 annual recharge from +14 to $+45 \%$. Recharge changes during the growing season (May 427 to October) varied between $-33 \%$ and $-4 \%$.

428 Lemieux et al. (2015) simulated the depth and shape of the groundwater transition

429 zone between freshwater and seawater in the Magdalen Islands (Québec; $200 \mathrm{~km}^{2}$ ). The 430 simulation of density-dependent flow was performed with the FEFLOW model along a 
431 vertical $2 \mathrm{D}$ cross section. The authors calculated recharge values using a surface water 432 budget and the climate scenario variables, and in the model imposed the recharge to 433 evolve linearly from current conditions to the worst-case recharge scenario (-30\%). In 434 these conditions, the impact of sea level rise was larger than that of both coastal erosion 435 and reduced recharge on the position of saltwater-freshwater interface which could 436 migrate inland over a distance of $37 \mathrm{~m}$.

437 Paradis et al. (2016) investigated how nitrate concentrations in groundwater might 438 evolve under climate change conditions and with changes in agricultural practices in 439 Prince Edward Island (PEI) $\left(5,660 \mathrm{~km}^{2}\right)$. The HELP model was used to simulate recharge 440 with climate scenarios used with a groundwater flow model developed in FEFLOW. 441 Nitrate concentrations resulting from residual soil nitrate for eight scenarios of 442 agricultural changes were simulated with the four recharge scenarios. The results showed 443 changes in annual recharge that ranged between $-12 \%$ and $+7 \%$. The generally increasing 444 nitrate concentrations were primarily attributed to the attainment of steady-state 445 conditions under present-day nitrogen loading, and to an increase in nitrogen loading in 446 some agricultural scenarios. Only $0 \%$ to $6 \%$ of the increase in nitrate concentrations in 447 groundwater was explained by changes in the recharge scenarios.

449 DISCUSSION

\section{Changes in recharge}

451 Comparing recharge rates between the different studies is not an easy task since recharge 452 is sometimes reported as mean annual values and sometimes as seasonal values. Some 453 studies simulate infiltration towards deeper soil (aquifer) layers, but do not explicitly 
454 quantify recharge (Quilbé et al. 2008; Levison et al. 2014b; CEHQ 2015). The studies 455 based on groundwater flow models (Bourgault et al. 2014; Green and MacQuarrie 2014; 456 Levison et al. 2014; Lemieux et al. 2015) have simulated worst-case recharge scenarios 457 and present the largest recharge decreases (maximum annual recharge decrease of 50\%, 458 Bourgault et al. 2014). Although these values are useful to plan for extreme conditions, 459 they do not necessarily reflect the complete array of possible future conditions.

460 Five out of six studies based on the HELP model show recharge increases (Brouwers 461 2007; Jyrkama and Sykes 2007; Kurylyk and MacQuarrie 2013; Rivard et al. 2014; 462 Motiee et al. 2017) while four out of six studies with integrated models show at least one 463 scenario with increased recharge (Colautti 2010; Sulis et al 2011; Sulis et al 2012; 464 Cochand 2014), and four out of six studies with integrated models show at least one 465 scenario with decreased recharge (Colautti 2010; Sultana and Coulibaly 2011; Sulis et al. 466 2012; Cochand 2014). Even though it is generally calibrated on total flow and baseflow 467 separation, HELP simulates water that percolates below the root zone. It is often not clear 468 whether or not this water reaches the aquifer and travel a significant distance with the 469 saturated zone. This could explain why, when these processes are considered in 470 integrated models where lateral and vertical aquifer heterogeneity is included, the 471 changes in recharge are less conclusive.

472 The reviewed studies do not show any clear trend from West to East. Apart from the 473 type of model used in the simulations, the discrepancies between studies could be due to 474 the climate models, to the post-processing methods, or to the projected horizons. 475 However, no clear causes could be identified with the available studies. The variability 476 introduced by these components of a study have been identified by Quilbé et al. (2008) 
477 and Kurylyk and MacQuarrie (2013). For example, GCMs poorly simulate precipitation

478 but statistical downscaling can improve the projected values and might be superior to the

479 delta change method since it can include changes in rainfall occurrence (Quilbé et al.

480 2008) which could impact recharge fluxes.

481 The studies generally agree that a global warming would reduce snow accumulation

482 during the winter. More frequent episodes of warmer temperatures, less snow

483 accumulation, and rain during winter are expected to increase winter recharge and lower

484 spring recharge. In the future projections, recharge is often higher in the winter and lower

485 in the spring season (Brouwers 2007; Colautti 2010; Sulis et al. 2011; Sultana and

486 Coulibaly 2011; Cochand 2014; CEHQ 2015). Sulis et al. (2012) also determined that

487 changes in the duration of the wet season had a large impact on recharge. However, the

488 dynamics of winter recharge still need to be investigated to fully understand how it will

489 be impacted by climate change.

490 The three studies that focused on coastal groundwater resources in similar geological

491 formations have shown contrasting results. Those of Hansen (2012) and Green and

492 MacQuarrie (2014) indicate that sea level rise would have a limited impact on salt water

493 intrusion, while that of Lemieux et al. (2015) showed that sea level rise would have the

494 largest impact (compared to erosion and change in recharge). Lemieux et al (2015) report

495 that when using a time frame similar to that of Green and MacQuarrie (2014), the impact

496 of sea level rise becomes more important in the Magdelen Island study. It should be

497 acknowledged that sea level rise can be locally variable, so its impacts on seawater

498 intrusion are expected to exhibit more spatial patterns than recharge changes. This

499 underlines an important component of climate change impact studies, i.e. that aquifers 
500 can react slowly to changes in recharge and other boundary conditions. Long-term and

501 continuous transient-state simulations are expected to better reflect the slow response of 502 aquifer reservoirs.

503 The studies also show that more inter-annual variability in recharge should be 504 expected during the summer, due to warmer air temperature and to more intense 505 precipitation generating runoff instead of recharge (not easily captured by models that are 506 based on a daily time step; Allen et al. 2014). This could induce longer drought periods 507 affecting the summer baseflows (Brouwers, 2007; Quilbé et al. 2008; Sulis et al. 2011; 508 Sultana and Coulibaly 2011; Cochand 2014; Levison et al. 2014a; CEHQ 2015). Also, if 509 recharge occurs earlier in the spring, small aquifers and those located in headwater basins 510 may be fully drained by summer months which would induce early low baseflow 511 conditions. Since municipal and agricultural users generally need more groundwater 512 during the summer period than during the winter, these changes could greatly affect 513 economic activities. This underlines the importance of representing soil and hillslope 514 storage variations through time and the importance of changing sequences of rainy days 515 on the simulation of recharge (Sulis et al. 2012). Again, this stresses the importance of 516 using long-term transient-state simulations.

518 Changes in groundwater discharge to surface water

519 Only one Ontario-based study (out of the three that reported baseflow values) showed 520 dominating conditions of decreased baseflows (McLaren and Sudicky 1993) while that of 521 Colautti (2010) showed mixed conditions. In Québec, generally decreasing baseflows 522 were reported (Quilbé et al. 2008; Sulis et al. 2011; Sulis et al 2012; Bourgault et al. 
523 2014; Cochand 2014; CEHQ 2015), but mixed conditions were also reported (Levison et

524 al. 2014a; 2014b). The only study in Atlantic Canada that reported baseflows (Kurylyk et

525 al. 2014) shows mainly increasing baseflows for a small granular aquifer.

526 Sulis et al. (2011) and Levison et al. (2014a) clearly identified that changes in local

527 aquifers near surface water bodies could lead to more frequent reversals of the hydraulic

528 gradient between aquifers and surface water bodies. These reversals lead to reductions in

529 baseflow and adds pressure on ecological habitats and water users in streams and ponds

530 during droughts and low water periods in summer (e.g., Levison et al. 2014b). The

531 absence of significant decreases in baseflows under climate change conditions in New

532 Brunswick can appear counterintuitive since Rivard et al. (2009) have identified

533 decreasing trends in baseflows in past time series for Atlantic Canada. However, the only

534 climate change impact study reported here (Kurylyk et al. 2014) concerns a very small

535 watershed which might not be representative of larger scale conditions.

536 Although early studies of the impact of climate change on water resources did not

537 include consideration of groundwater flow (e.g., Southam et al. 1999), the most recent

538 studies using surface flow models incorporate at least a simplified representation of

539 aquifer reservoirs (e.g., Quilbé et al. 2008; CEHQ 2015). In these cases, the surface flow

540 model simulates baseflows which can be attributed to a groundwater contribution to the

541 river and changes in these flows under climate change conditions can be studied.

542 Interestingly, four out of five applications of integrated models show at least one scenario

543 with baseflow decrease while two out of five applications show at least one scenario of

544 baseflow increase. It is self-evident that integrated surface water-groundwater models

545 simulate more completely and probably more reliably baseflow conditions. However, in 
546 this review, the baseflow results appeared to be independent of the type of model

547 (groundwater flow or integrated surface-groundwater flow model). They also appeared to

548 be independent of the climate model, and of the post-processing method.

549

550 Climate change impacts in conjunction with other pressures

551 Agricultural, urban and potable water pressures on groundwater availability are 552 already of concern in most of the inhabited regions in Eastern Canada. Climate change is 553 expected to influence indirectly groundwater use which can evolve through climate554 driven or socio-economically-driven land use change (Taylor et al. 2012). Water quantity 555 stress assignments have been performed on the Grand River watershed and elsewhere to 556 investigate the effect of possible future increases of water use on water availability (e.g., 557 AquaResources 2009a; 2009b) and water use conflicts (e.g., Lavigne et al. 2010a; 558 2010b). Kurylyk and MacQuarrie (2013) proposed that when studying recharge on a 559 projected horizon longer than a few decades, land use changes and socio-economic 560 factors should be taken in consideration. Nikolic and Simonovic (2015) (not reported in 561 detail herein because the paper did not provide quantified changes in recharge or 562 baseflows) have shown that at the sub-watershed scale, increasing permits to take water 563 for agriculture could have an adverse impact on the groundwater resources. Bourgault et 564 al. (2014) provide similar results and showed that increased groundwater pumping could 565 have a larger impact on groundwater resources than decreased recharge in a St. Lawrence 566 Lowlands granular superficial aquifer. Hansen (2012) and Green and MacQuarrie (2014) 567 have shown that groundwater use through pumping in coastal aquifers can exacerbate 568 saltwater intrusion. Analytical solutions have been developed to better apprehend these 569 conditions and help water managers (e.g., Ferguson and Gleeson 2012). 
570 Changing land use through deforestation, expansion or changes in agricultural 571 activities or urban areas, and drainage of wetlands can have impacts on surface and 572 subsurface hydrology (Mishra et al. 2010). For example, Fossey et al. (2016) have used 573 surface flow modeling to show that isolated wetlands located in the upper part of a 574 watershed have a larger effect on maintaining low flows and damping high flow than 575 wetlands located downstream. If wetland drainage is combined with a dryer or flashier 576 future climate, the impacts of groundwater and surface water resources could be 577 exacerbated. Paradis et al. (2016) have also shown that changes in nitrogen loading that 578 could be a consequence of increased temperatures leading to different crop choices, or 579 that could result from the intensification of agricultural activities, would have a larger 580 impact on groundwater nitrate concentrations than changes in recharge.

\section{$582 \quad$ Modelling at different scales}

583 The reviewed studies cover a large range of scales. Local scale studies $\left(<100 \mathrm{~km}^{2}\right)$ 584 (Brouwer 2007; Hansen 2012; Kurylyk and MacQuarrie 2013), usually need strong 585 collaborative support from specialists familiar with the regional geology and the local 586 characteristics (Frey et al. 2016). Data is often most available at the watershed scale (100 587 to $1,000 \mathrm{~km}^{2}$ ) where watershed organizations contribute to knowledge acquisition and 588 data availability. At that scale, most of the studies of the last decade have been 589 implemented with integrated models (Colautti 2010; Sultana and Coulibaly 2011; Sulis et 590 al. 2011; 2012; Cochand 2014; Levison et al. 2014b). Groundwater flow models are still 591 used (Levison et al. 2014a; Kurylyk et al. 2014; Lemieux et al. 2015; Levison et al. 592 2016), but they necessitate simplifications in the recharge processes or the coupling of a 593 recharge model to a groundwater flow model (e.g., Kurylyk et al. 2014; Paradis et al. 
594 2016). This has unquantified impacts on the simulated conditions and the surface595 unsaturated zone-saturated aquifer feedback processes.

596 At the regional scale (2,000 to $\left.10,000 \mathrm{~km}^{2}\right)$ hydrogeological data and detailed 597 descriptions of aquifer properties do not always exist. Major funding has been invested in 598 aquifer characterization in the Province of Québec in the last decade (see MDDELCC 5992017 a for a full list of reports since 2009). In Ontario, there have been many regional 600 scale hydrogeological studies since the 1980s and 1990s (e.g., Howard and Beck 1986; 601 Novakowski and Lapcevic 1988; Sharpe et al. 1996; Rudolph et al. 1998). These detailed 602 groundwater data over a large region, such as in the Grand River watershed in Ontario, 603 allowed researchers to develop complete groundwater description and integrated models 604 (Jyrkama and Sykes 2007; Colautti 2010). In Atlantic Canada, the Canadian Geological 605 Survey has performed regional hydrological characterization studies in the last decade as 606 part of the Canadian Groundwater Inventory (Paradis et al. 2007; Rivard et al. 2008; 607 Rivard et al. 2012). All these initiatives have led to the development of databases that can 608 support model development for climate change studies.

609 Climate change impacts on the groundwater dynamics in Eastern Canada have not yet 610 been investigated on a provincial scale. Natural Resources Canada has recently initiated 611 the development of a fully-integrated groundwater-surface water, climate impact model 612 for the southern Ontario Phanerozoic Basin Region (Frey et al. 2016; NRCan 2017). The 613 Québec Ministry of Environment (MDDELCC) has recently initiated the development of 614 an integrated groundwater-surface water model for southern Québec that will be used to 615 better understand the impact of climate change on water resources. These models will 616 facilitate anticipating long-term changes over large areas, including those resulting from 
617 climate change. This is clearly a positive development towards integrated water 618 management and adaptation for future conditions. These models could include other 619 cumulative stresses occurring on groundwater resources, such as changes in land use and 620 increasing pumping for drinking water, industrial or irrigation purposes. The combination 621 of studies and models existing at different scales, developed with various purposes in 622 mind, will truly aid decision making for groundwater management.

\section{Uncertainty in future conditions}

625 The large range of possible future recharge conditions in Eastern Canada is not 626 uncommon in climate change studies. It has been reported elsewhere and appears to be 627 intrinsic to the study of climate change effects (e.g., Green et al. 2011). This variability 628 can be due to the use of various climate models, emissions scenarios, data treatment 629 methods (e.g., downscaling), and future time horizons. Although some studies have 630 aimed specifically at better understanding this component and argue that using different 631 downscaling methods and different sources of data is a necessity (Quilbé et al. 2008), the 632 studies reviewed here did not allow to identify which of these methods should be 633 prioritized over others.

634 Variability in the results also comes from the flow models themselves, notably from 635 over-simplification of the geological conditions stemming from insufficient 636 hydrogeological data used to build the model. The type of modeling approach to be used 637 is also crucial to the array of possible future conditions. The review presented here 638 indicates that coherent results appear between the three regions when similar modeling 639 approaches are used. Among these, and rather intuitively, the integrated surface- 
640 groundwater flow models may be more robust to simulate climate change impacts. They

641 allow a more holistic understanding of the entire water cycle and of the feedbacks

642 between reservoirs, within a single mathematical framework, thus alleviating time and

643 spatial scale errors. Going one step further, Sulis et al. (2017) report an application of

644 coupling water flow, vegetation and atmospheric processes in western Germany. This

645 type of integrated approach is expected to become increasingly used as computer 646 capacities continue to increase in the next decade.

647 Using short time series of heads and flow rate data for model calibration data can also 648 be responsible for model uncertainty because they do not include a wide array of possible 649 meteorological and hydrological conditions (Moeck et al. 2016). A model that has been 650 calibrated based on years of wet conditions is not necessarily robust to simulate dry 651 conditions, or a succession of wet and dry periods. This is certainly a challenge, and 652 although most Canadian provinces have a reasonably well maintained surface water 653 monitoring network, groundwater monitoring has only recently received serious 654 attention. Recent efforts have been invested in Québec since 2000 to install a province655 wide groundwater monitoring network (MDDELCC 2017b). Ontario has had the 656 Provincial Groundwater Monitoring Network since 2001, which has 492 monitoring 657 points across the province (MOECC 2017). In Nova Scotia, the Groundwater 658 Observation Well Network was established in 1965 and currently hosts 40 observation 659 wells (Government of Nova Scotia, 2017). In New Brunswick, the groundwater 660 observation well network was established in the early 1970s, was disbanded in 2000 and 661 is currently being re-instrumented with a limited number of stations. In Prince Edward 662 Island, groundwater elevations are available for 14 monitoring wells, with data from as 
663 early as the 1967 for some wells available online (Government of Prince Edward Island, 664 2017).

665

\section{Recommendations}

667 The first recommendation from this review is that multiple scenarios from an array of 668 climate models and different climate change scenarios should be used. This follows 669 recommendations by Holman et al. (2011), and was observed in most of the reviewed 670 studies. The most recent studies use RCP scenarios and span future horizons that reach 671 2100. It is now relatively easy for researchers, consultants and water managers who wish 672 to perform climate change impact studies to have access to databases that provide 673 downscaled climate data across Canada. For example, the Pacific Climate Impacts 674 Consortium provides temperature and precipitation data from statistically downscaled 675 climate scenarios (on a grid of approximately $10 \mathrm{~km}$ resolution) for the entire country for 676 1950-2100 (https://www.pacificclimate.org/data/statistically-downscaled-climate$677 \underline{\text { scenarios)}}$. The Climate Change Data Portal (http://ccdp.network/) also provides 678 dynamically downscaled climate change scenarios (temperature and precipitation) for 679 Canada and other regions of the world. The Ouranos Consortium provides on demand 680 climate scenarios based on regional or global climate models and is currently developing 681 a web-access platform to make climate scenarios publicly available (PAVICS - Power 682 Analytics and Visualization for Climate Science).

683 The decision of which model to use is often not an easy one since it depends on 684 available data, available time to perform the study and local expertise. Nevertheless, 685 some insights arise from this review. It is clear that surface flow models provide only 
686 limited insight to the impact of climate change on groundwater resources because they

687 use highly simplified representations of aquifers and generally not calibrated to fully 688 represent baseflow conditions. They are thus not the preferred tool when studying climate 689 change impacts on groundwater resources. Groundwater flow models are useful to 690 understand conditions in specific areas, but they are tributary to the separate simulation of 691 recharge processes and this adds some level of uncertainty in the simulation of climate 692 change impacts. Integrated surface water-groundwater flow models are a logical 693 approach to understand the impacts of climate change on water resources, and the 694 feedbacks between different water reservoirs. The second recommendation is that these 695 models should be favored when possible in future studies.

696 This review also highlighted the important spatial variability in simulated changes for 697 recharge and baseflows. This variability can only be taken into account by using models 698 at different scales, depending on the issues under consideration. Local models, watershed 699 models, regional or supra-regional models all contribute to better understanding this 700 variability and to provide managers with decision-making tools. Topographic location, 701 geological conditions have been identified as having a possible influence on how aquifers 702 will respond to climate change. This review also has underlined the importance of 703 performing long term transient-state simulations to assess the impact of temporal 704 variability, as well as the long-term storage potential of aquifers. The third 705 recommendation is that model efforts should represent long-term climate change impacts 706 at different scales.

707 Other anthropogenic pressures such as land use changes and increased pumping rates 708 are also of crucial importance to assess combined effects and cumulated impacts. The 
709 fourth recommendation is that these should be included in future studies to provide a 710 background of information to assess tipping points for groundwater resources and 711 ecosystems. The case of cumulated impacts on coastal groundwater resources has been 712 made in this review. The impact of climate change on groundwater dependent ecosystems 713 subjected to land development pressure and contamination should also be further 714 investigated.

715 Spatial coverage of the territory of Eastern Canada is another important issue. The 716 studies of climate change impacts on groundwater resources have yet focused only in the 717 southern part of Eastern Canada. The fifth recommendation is that more studies should be 718 performed to assess the impact of climate change in Northern Ontario, North of the St. 719 Lawrence River, and in the Bas-Saint-Laurent and Gaspésie regions, as well as in 720 Newfoundland and Labrador. Additional studies would also be useful to better 721 understand how salt water intrusion will be affected by sea level rise, changes in recharge 722 and pumping in coastal regions of Québec and Atlantic Canada. Locations/regions for 723 future studies should be prioritized based on criteria such as expected increases in water 724 supply demand, ecological flow requirements, resource extraction, and other issues 725 relevant to provincial and municipal governments. This may shift as governmental 726 priorities evolve in each province. Stakeholders who also often provide funding for this 727 type of research (e.g., provincial environment and agricultural ministries, in consultation 728 with other interested parties) can continue to set priorities for critical locations for future 729 investigation based on the above criteria. 


\section{CONCLUSION}

732 This paper aimed to review the state of knowledge about simulated climate change

733 impacts on groundwater dynamics in Eastern Canada, including the provinces of Ontario,

734 Québec, New Brunswick, Nova Scotia, and Prince Edward Island. Three major issues

735 have been highlighted from these studies: i) no overall trend in time or space in recharge

736 could be identified from the reviewed studies, but for Eastern Canada, but more inter-

737 annual variability throughout the year is expected due to seasonal shifts in recharge; iii)

738 groundwater discharge to surface water bodies tends to be reduced in future scenarios,

739 and particularly during summer droughts. This exercise has provided a valuable reflection

740 of our current understanding of possible future conditions. The analysis contributed to

741 identifying how to improve climate change impact studies in such a way that they can be

742 more useful for water managers.

743 There is clearly a need to establish guidelines for performing climate change impact

744 studies on groundwater resources. This review provided new insights that lead to the

745 following five recommendations for future studies: 1) use a variety of climate models and

746 emission scenarios; 2) promote the use of integrated models when possible; 3) study

747 long-term climate change impacts on groundwater resources at different scales; 4)

748 simulate the combined effects of climate change and other pressures; and 5) develop

749 models that cover other regions of Eastern Canada as dictated by stakeholders and water

750 managers. It is clear that a good understanding of aquifer geometry and groundwater

751 flow dynamics, a dense coverage of long-term monitoring stations for piezometric heads

752 and river flow rates, and the development of integrated models that are maintained in the

753 long-term would facilitate water management and planning in a changing climate. 


\section{Acknowledgements}

757 The authors would like to thank the Québec Ministry of Agriculture, Fisheries and 758 Food (MAPAQ-Ministère de l'Agriculture, des Pêcheries et de l'Alimentation du 759 Québec) and the Ontario Ministry of Agriculture, Food, and Rural Affairs (OMAFRA) 760 for funding this research.

761 


\section{References}

763 Allen, D.M., M. Hayashi, M. Nastev, Z. Chen, and B. Turner. 2014. Recharge and 764 climate. In: Canada's groundwater resources. Edited by A. Rivera. Fitzhenry and 765 Whiteside, Markham, Ontario, Canada, pp 101-139.

AquaResources. 2009a. Integrated Water Budget Report - Grand River Watershed. Report prepared for the Grand River Conservation Authority. 224 p.

AquaResources. 2009b. Tier 2 Water Quantity Stress Assessment Report - Grand River

Bedekar, V., E.D. Morway, C.D. Langevin, and M. Tonkin. 2016, MT3D-USGS version transport capabilities for use with MODFLOW: U.S. Geological Survey Techniques and Methods 6-A53, 69 p., http://dx.doi.org/10.3133/tm6A53 interactions under climate change. Hydrology Research, 45(3):425-440.

Brouwers, M.H. 2007. A case study for assessing the hydrologic impacts of climate change at the watershed scale. PhD thesis, University of Waterloo, Ontario, $131 \mathrm{p}$.

778 Camporese, M., C. Paniconi, M. Putti, and S. Orlandini. 2010. Surface-subsurface flow 779 modeling with path-based runoff routing, boundary condition-based coupling, and 780 assimilation of multisource observation data, Water Resources Research, 46, W02512, 781 doi: 10.1029/2008WR007536. 
782 Castle, S.L., B.F. Thomas, J.T. Reager, M. Rodell, S.C. Swenson, J.S. Famiglietti. 2014.

783 Groundwater depletion during drought threatens future water security of the Colorado

784 Basin. Geophysical Research Letters, 41, 5904-5911, doi:10.1002/2014GL061055.

785 Centre d'expertise hydrique du Québec (CEHQ). 2015. Atlas hydroclimatique du Québec

786 méridional - Impact des changements climatiques sur les régimes de crue, d'étiage et 787 d'hydraulicité à l'horizon 2050. Québec, 81 p.

788 Chen, J. 2015. Impact of Climate Change on Canadian Water Resources: A Continental789 Scale Hydrologic Modelling Study Using Multiple RCM Projections. PhD Thesis, $790 \quad$ University of Waterloo, Ontario, Canada. 135 p.

791 Climate action network. 2017. Impacts in Canada. $792 \mathrm{http}$ //climateactionnetwork.ca/issues/impacts-and-adaptation/learning-cente/impacts793 in-canada/, web page accessed in May 2017.

794 Cochand, F. 2014. Impact des changements climatiques et du développement urbain sur 795 les ressources en eaux du bassin versant de la rivière Saint-Charles. PhD thesis, 796 Université Laval, Québec, Canada. 212 p.

797 Colautti, D. 2010, Modelling the Effects of Climate Change on the Surface and 798 Subsurface Hydrology of the Grand River Watershed. PhD Thesis, University of 799 Waterloo, Waterloo, Ontario, Canada, 129 p.

800 Crosbie, R.S., B.R. Scanlon, F.S. Mpelasoka, R.C. Reddy, J.B. Gates, and L. Zhang. 801 2013. Potential climate change effects on groundwater recharge in the High Plains 802 Aquifer, USA. Water Resources Research, 49:3936-3951, doi:10.1002/wrcr.20292, 8032013. 
804 De Graaf, I.E.M., R.L.P.H. van Beek, T. Gleeson, N. Moorsdorf, O. Schmitz, E.H. 805 Sutanudjaja, and M.F.P. Birkens. 2017. A global-scale two-layer transient 806 groundwater model: Development and application to groundwater depletion. Advances 807 in Water Resources, 102: 53-67.

DHI Software. 2007. MIKE SHE User Manual, Volume 2: Reference Guide. Hørsholm, 809

DHI-WASY. 2013. FEFLOW finite element subsurface flow and transport simulation Danemark. 385 p. system-user's manual/reference manual/ white papers, Version 6.1. Technical Report. DHI-WASY GmbH, Berlin.

817 assessment of groundwater depletion and related groundwater abstractions:

818 Combining hydrological modeling with information from well observations and 819 GRACE satellites. Water Resources Research, 50, 5698-5720, 820 doi:10.1002/2014WR015595.

821 D’Orgeville, M., Peltier, W.R., Erler, A.R., and Gula, J. 2014. Climate change impacts on 822 Great Lakes Basin precipitation extremes. Journal of Geophysical Research, 823 Atmospheres, 119: 10 799-10 812. 
824 Environment and Climate Change Canada (ECCC). 2017. Groundwater. 825 https://www.ec.gc.ca/eau-water/, web page accessed in May 2017.

826 Ferguson, G., and T. Gleeson. 2012. Vulnerability of coastal aquifers to groundwater use 827 and climate change. Nature Climate Change Letters, 2: 342-345, DOI: $828 \quad$ 10.1038/NCLIMATE1413.

829 Food and Agriculture Organization of the United Nations (FAO). 2003. Review of World 830 water resources by country. World Water Reports 23.

831 Fortin, J.P., R. Turcotte, S. Massicotte, R. Moussa, J. Fitzback, and J.P. Villeneuve. 2001. 832 A Distributed Watershed Model Compatible with Remote Sensing and GIS Data. Part 833 I: description of the Model. Journal of Hydrologic Engineering 6(2): 91-99.

834 Fossey, M., A.N. Rousseau, and S. Savary. 2016. Assessment of the impact of spatio835 temporal attributes of wetlands on stream flows using a hydrological modelling 836 framework: a theoretical case study of a watershed under temperate climatic 837 conditions. Hydrological Processes 30:1768-1781.

838 Frey, S.K., S.J. Berg, and E.A. Sudicky. 2016. A Feasibility Study of Merits and 839 Development Strategies for a Regional Water Resources Modelling Platform for 840 Southern Ontario - Great Lakes Basin. Geological survey of Canada, Open file 8021, $841 \quad$ Natural Resources Canada, 46 p.

842 Giorgi F., and Mearns, L. 1991. Approaches to the simulation of regional climate change: 843 A review. Reviews of Geophysics 29:191-216. 
844 Government of Nova Scotia. 2017. Groundwater Observation Well Network. 845 https://novascotia.ca/nse/groundwater/groundwaternetwork.asp

846 Government of Prince Edward Island. 2017. View Groundwater Level Data. 847 https://www.princeedwardisland.ca/en/service/view-groundwater-level-data

848 Green, T.R., M. Taniguchi, H. Kooi, J.J. Gurdak, D.M. Allen, K.M. Hiscock, H. Treidel, 849 and A. Aureli. 2011. Beneath the surface of climate change: Impacts of climate change 850 on groundwater. Journal of Hydrology, 405:532-560.

851 Green, N.R., and K.T.B. MacQuarrie. 2014. An evaluation of the relative importance of 852 the effects of climate change and groundwater extraction on seawater intrusion in 853 coastal aquifers in Atlantic Canada. Hydrogeology Journal, 22(3):609-623.

854 Guo, W., and C.D. Langevin. 2002. User's guide to SEAWAT: a computer program for 855 simulation of three-dimensional variable-density ground-water flow. US Geological 856 Survey, Reston, VA.

857 Hansen, B.A. 2012. Simulating the effects of climate change on a coastal aquifer, 858 Summerside, Prince Edward Island. PhD thesis, Saint Francis Xavier University, Nova $859 \quad$ Scotia, $105 \mathrm{p}$.

860 Harbaugh AW. 2005. MODFLOW-2005, the U.S. Geological Survey modular ground861 water model - the ground-water flow process: U.S. Geological Survey techniques and 862 methods 6-A16. Various pp. http://pubs.usgs.gov/tm/2005/tm6A16/. 
863 Holman, I.P., D.M. Allen, M.O. Cuthbert, and P. Goderniaux. 2011. Towards best 864 practice for assessing the impacts of climate change on groundwater. Hydrogeology 865 Journal, 20:1-4.

866 Howard, K.W.F, and P. Beck. 1986. Hydrochemical interpretation of groundwater flow 867 systems in Quaternary sediments of southern Ontario. Canadian Journal of Earth $868 \quad$ Sciences, 23:938-947.

869 Intergovernmental Panel on Climate Change (IPCC). 2000. Special report on emission 870 scenarios Nebojsa Nakicenovic and Rob Swart (Eds.) Cambridge University Press, 871 UK. pp 570. Cambridge University Press, Cambridge, UK, 570 p.

872 Intergovernmental Panel on Climate Change (IPCC). 2013. Climate Change 2013: The 873 Physical Science Basis. Contribution of Working Group I to the Fifth Assessment 874 Report of the Intergovernmental Panel on Climate Change [Stocker, T.F., D. Qin, G.875 K. Plattner, M. Tignor, S.K. Allen, J. Boschung, A. Nauels, Y. Xia, V. Bex and P.M. 876 Midgley (eds.)]. Cambridge University Press, Cambridge, United Kingdom and New 877 York, NY, USA, 1535 p.

878 Jacobs, E.E. 2011. The application of the HELP model to examine the potential impact of 879 climate change on recharge rates in coastal regions of New Brunswick. Research 880 report, Dept. of Civil Engineering, University of New Brunswick, Fredericton, NB, 32 $881 \quad$ pp.

882 Jyrkama, M.I., and J.F. Sykes. 2007. The impact of climate change on spatially varying 883 groundwater recharge in the Grand River watershed (Ontario). Journal of Hydrology, $884 \quad 338(3-4): 237-250$. 
885 Kløve, B, P. Ala-Aho, G. Bertrand, J.J. Gurdak, H. Kupfersberger, J Kværner, T. 886 Muotka, H. Mykrä, E. Preda, P. Rossi, C. Bertacchi Uvo, E. Velasco, and M.1 Pulido887 Velazquez. 2014. Climate change impacts on groundwater and dependent ecosystems. $888 \quad$ Journal of Hydrology 518: 250-266.

Kurylyk, B.L., and K.T.B. MacQuarrie. 2013. The uncertainty associated with estimating 890 future groundwater recharge: A summary of recent research and an example from a 891

Lavigne, M.A., M. Nastev, and R. Lefebvre. 2010b. Regional Sustainability of the

Lemieux, J.M., J. Hassaoui, J. Molson, R. Therrien, P. Therrien, M. Chouteau, and M. Ouellet 2015. Simulating the impact of climate change on the groundwater resources of the Magdalen Islands, Québec, Canada. Journal of Hydrology: Regional Studies $3: 400-423$ 
905 Levison, J.K., Larocque, M., Fournier, V., Gagné, S., Pellerin, S., and Ouellet, M.A. 906 2014a. Dynamics of a headwater system and peatland under current conditions and 907 with climate change. Hydrological Processes 28 (17):4808-4822.

908 Levison, J.K., M. Larocque, and M.A. Ouellet. 2014b. Modeling low-flow bedrock 909 springs providing ecological habitats with climate change scenarios. Journal of $910 \quad$ Hydrology 515:16-28.

911 Levison, J.K., M. Larocque, M.A. Ouellet, O. Ferland, and C. Poirier. 2016. Long-term 912 trends in groundwater recharge and discharge in a fractured bedrock aquifer - past and 913 future conditions. Canadian Water Resources Journal 41(4):500-514.

914 Lindström G., B. Johansson, M. Persson, M. Gardelin, and S. Bergström. 1997. 915 Development and test of the distributed HBV-96 hydrological model. Journal of $916 \quad$ Hydrology 201:272-88.

917 McLaren, R., and E. Sudicky. 1993. The impact of climate change on groundwater. M. 918 Sanderson (ed.), The impact of climate change on water in the Grand River basin, 919 Ontario. Waterloo, Ontario: University of Waterloo, Department of Geography. pp. $920 \quad 53-67$.

921 Meehl, G.A., C. Covey, T. Delworth, M. Latif, B. McAvaney, J.F.B. Mitchell, R.J. 922 Stouffer, and K.E. Taylor. 2007. The WCRP CMIP3 Multimodel Dataset: A New Era 923 in Climate Change Research, Bulletin of the American Meteorological Society, 1383924 1394. doi: org/10.1175/BAMS-88-9-1383

925 Mishra, V., K.A. Cherkauer, D. Niyogi, M. Lei, B.C. Pijanowski, D.K. Ray, L.C. 926 Bowling, and G. Yang. 2010. A regional scale assessment of land use/land cover and 
927 climatic changes on water and energy cycle in the upper Midwest United States, 928 International Journal of Climatology, 30:2025-2044.

929 Ministère du Développement durable, Environnement et Lutte contre les changements 930 climatiques du Québec (MDDELCC). 2017a. Programme d'acquisition de 931 connaissances sur les eaux souterraines.

932 http://www.mddelcc.gouv.qc.ca/eau/souterraines/programmes/acquisition-

933 connaissance.htm.

934 Ministère du Développement durable, Environnement et Lutte contre les changements 935 climatiques du Québec (MDDELCC). 2017b. Réseau de suivi des eaux souterraines. 936 http://www.mddelcc.gouv.qc.ca/eau/piezo/index.htm.

937 Ministry of the Environment and Climate Change (MOECC). 2017. Provincial 938 Groundwater Monitoring Network. https://www.ontario.ca/data/provincial939 groundwater-monitoring-network

940 Moeck, C., P. Brunner, and D. Hunkeleer. 2016. The influence of model structure on 941 groundwater recharge rates in climate-change impact studies. Hydrogeology Journal, $942 \quad 24: 1171-1184$.

943 Motiee, H., and E. McBean. 2017. Assessment of climate change impacts on groundwater 944 recharge for different soil types-Guelph region in Grand River basin, Canada. 945 ECOPERSIA 5(2):1731-1744.

946 Music, B., and D. Caya. 2007. Evaluation of the Hydrological Cycle over the Mississippi 947 River Basin as Simulated by the Canadian Regional Climate Model (CRCM). Journal 948 of Hydrometeorology 8(5):969-988. 
949 Natural Resources Canada (NRCan). 2017. Proof of Concept: Fully integrated 950 groundwater -surface-water model for the Phanerozoic Basin Region of Southern 951 Ontario, Request for Proposal (RFP): NRCan- 5000030852.

952 Nikolic V.V., and S.P. Simonovic. 2015. Multi-method modeling framework for support 953 of integrated water resources management. Environmental Processes 2:461-483. DOI $954 \quad 10.1007 / \mathrm{s} 40710-015-0082-6$

955 Novakowski, K.S., and P.A. Lapcevic. 1988. Regional hydrogeology of the Silurian and 956 Ordovician sedimentary rock underlying Niagara Falls, Ontario, Canada. Journal of $957 \quad$ Hydrology 104(1-4):211-236.

958 Ouranos. 2015. Vers l'adaptation. Synthèse des connaissances sur les changements 959 climatiques au Québec. Montréal, Québec : Ouranos. 415 p.

960 Paradis, D., J.M. Ballard, and R. Lefebvre. 2007. Watershed scale numerical modelling 961 of nitrate fate and transport using spatially uniform averaged $N$-inputs. In: 962 Consequences of climatic changes on contamination of drinking water by nitrates on 963 Prince Edward Island, Report of the Climate Change Action Fund: Impacts and 964 Adaptation (A881/A843), edited by: Savard, M. M. and Somers, G., Natural 965 Resources Canada, Quebec City, pp. 49-62.

966 Paradis, D., H. Vigneault, R. Lefebvre, M.M. Savard, J.M. Ballard, and B. Qian. 2016. 967 Groundwater nitrate concentration evolution under climate change and agricultural 968 adaptation scenarios: Prince Edward Island, Canada. Earth System Dynamics 7:183969202. 
970 Quilbé, R., A.N. Rousseau, J.S. Moquet, N.B. Trinh, Y. Dibike, P. Gachon, and D.

971 Chaumont. 2008. Assessing the effect of climate change on river flow using general 972 circulation models and hydrological modelling - Application to the Chaudière River, 973 Québec, Canada. Canadian Water Resources Journal 33(1):73-94.

974 Rivard, C., Y. Michaud, C. Deblonde, V. Boisvert, C. Carrier, R.H. Morin, T. Calvert, H. 975 Vigneault, D. Conohan, S. Castonguay, R. Lefebvre, A. Rivera, and M. Parent. 2008. 976 Canadian Groundwater Inventory: Regional hydrogeological characterization of the 977 south-central part of the Maritimes Basin; Geological Survey of Canada, Bulletin 589, $97896 \mathrm{p}$.

979 Rivard, C., H. Vigneault, A.R. Piggott, M. Larocque, and F. Anctil. 2009. Groundwater 980 recharge trends in Canada. Canadian Journal of Earth Sciences 46(11):841-854.

981 Rivard, C., D. Paradis, S.J. Paradis, A. Bolduc, R.H. Morin, S. Liao, S. Pullan, M.J. 982 Gauthier, S. Trépanier, A. Blackmore, I. Spooner, C. Deblonde, R. Boivin, R.A. 983 Fernandes, S. Castonguay, T. Hamblin, Y. Michaud, J. Drage, and C. Paniconi, C. 984 2012. Canadian Groundwater Inventory: regional hydro-geological characterization of 985 the Annapolis Valley aquifers, Geological Survey of Canada, Bulletin 598, 152 p. 986 doi:10.4095/288107

987 Rivard, C., C. Paniconi, H. Vigneault, and D. Chaumont. 2014. A watershed-scale study 988 of climate change impacts on groundwater recharge (Annapolis Valley, Nova Scotia, 989 Canada). Hydrological Sciences Journal, 59(8):1437-1456, DOI: 10.1080/02626667. $990 \quad 2014.887203$. 
991 Rudolph, D.L., D.A.J Barry, M.J. Goss. 1998. Contamination in Ontario farmstead 992 domestic wells and its association with agriculture: 2. Results from multilevel 993 monitoring well installations, Journal of Contaminant Hydrology 32(3-4):295-311.

994 Sanderson, M., and J.V Smith. 1993. The present and $2 \mathrm{x} \mathrm{CO}_{2}$ climate and water balance 995 in the basin. M. Sanderson (ed.), The impact of climate change on water in the Grand 996 River basin, Ontario. Waterloo, Ontario: University of Waterloo, Department of 997 Geography. pp. 3-24.

998 Schroeder, P.R., T.S. Dozier, P.A. Zappi, B.M. McEnroe, J.W. Sjostrom, and R.L. 999 Peyton. 1994. The Hydrologic Evaluation of Landfill Performance (HELP) Model: 1000 Engineering documentation for version 3. EPA/600/R-94/168b, US Environmental 1001 Protection Agency Office of Research and Development, Washington, DC.

1002 Sharpe, D.R., L.D. Dyke, M.J. Hinton, S.E. Pullan, H.A.J. Russell, T.A. Brennand, P.J. 1003 Barnett, and A. Pugin. 1996. Groundwater prospects in the Oak Ridges Moraine area, 1004 southern Ontario: application of regional geological models; in Current Research 1005 1996-E; Geological Survey of Canada, p. 181-190.

1006 Southam, C.F., B.N. Mills, R.J. Moulton, and D.W. Brown. 1999. The potential impact of 1007 climate change in Ontario's Grand River basin: Water supply and demand issues, 1008 Canadian Water Resources Journal, 24(4):307- 328.

1009 Statistics Canada. 2016. Population by year, by province and by territory. Government of 1010 Canada. $\quad$ http://www.statcan.gc.ca/tables-tableaux/sum-som/101/cst01/demo02a1011 eng.htm. Web page accessed in June 2017. 
1012 Statistics Canada. 2012. Agricultural water use in Canada. Government of Canada, 1013 Catalogue no. 16-402-X, December 2013, 39 p.

1014 Sulis, M., C. Paniconi, C. Rivard, R. Harvey, and D. Chaumont. 2011. Assessment of 1015 climate change impacts at the catchment scale with a detailed hydrological model of 1016 surface-subsurface interactions and comparison with a land surface model, Water 1017 Resources Research 47(1), W01513.

1018 Sulis, M., C. Paniconi, M. Marrocu, D. Huard, and D. Chaumont. 2012. Hydrologic 1019 response to multimodel climate output using a physically based model of 1020 groundwater/surface water interactions. Water Resources Research 48(12), W12510.

1021 Sulis, M., J.L. Williams, P. Shrestha, M. Diederich, C. Simmer, S.J. Kollett, and R.M. 1022 Maxwell. 2017. Coupling groundwater, vegetation, and atmospheric processes: a 1023 comparison of two integrated models. J. Hydrometeorology 18:1489-1511.

1024 Sultana, Z., and P. Coulibaly. 2011. Distributed modelling of future changes in 1025 hydrological processes of Spencer Creek watershed. Hydrological Processes 25:12541026 1270. DOI:10.1002/hyp.7891.

1027 Taylor, K.E., R.J. Stouffer, and G.A. Meehl, 2012: An Overview of CMIP5 and the 1028 experiment Design. Bulletin of the American Meteorological Society, 93, 485-498. 1029 doi: 10.1175/BAMS-D-11-00094.1.

1030 Taylor, R, G., B. Scanlon, P. Döll, M. Rodell, R. van Beek, Y. Wada, L. Longuevergne, 1031 M. Leblanc, J.S. Famiglietti, M. Edmunds, L. Konikow, T.R. Green, J. Chen, M. 1032 Taniguchi, M.F.P. Bierkens, A. MacDonald, Y. Fan, R.M. Maxwell, Y. Yechieli, J.J. 1033 Gurdak, D.M. Allen, M. Shamsudduha, K. Hiscock, P.J.-F. Yeh, I. Holman, and H. 
1034 Treidel. 2012. Ground water and climate change. Nature Climate Change, $1035 \quad$ http://dx.doi.org/10.1038/nclimate1744.

1036 Teutschbein C, and J. Seibert. 2012. Bias correction of regional climate model 1037 simulations for hydrological climate change impact studies: Review and evaluation of 1038 different methods. Journal of Hydrology 456-457: 12-29.

1039 Themeß1, M.J., A. Gobiet, and A. Leuprecht. 2010. Empirical-statistical downscaling and 1040 error correction of daily precipitation from regional climate models. Int. J. Climatol., $1041 \quad 31,1530-1544$, doi:10.1002/joc.2168.

1042 Therrien, R., R.G. McLaren, E.A. Sudicky, and S.M. Panday. 2010. A three-dimensional $1043 \quad$ numerical model describing fully-integrated subsurface and surface flow and solute 1044 transport. User Guide. Waterloo, Ontario, $456 \mathrm{p}$.

1045 van Vuuren, D.P., J. Edmonds, M. Kainuma, K. Riahi, A. Thomson, K. Hibbard, G.C. 1046 Hurtt, T. Kram, V. Krey, J.F. Lamarque, T. Masui, M. Meinshausen, N. Nakicenovic, 1047 S.J. Smith, and S.K. Rose. 2011. The representative concentration pathways: an 1048 overview. Climatic Change, 109:5-31.

1049 Voss, C.I., and A.M. Provost. 2002. SUTRA: A model for saturated-unsaturated variable1050 density ground-water flow with solute or energy transport. Water Resour. Invest. Rep. 1051 02-4231, 201 pp., U.S. Geol. Surv., Reston, VA. 


\section{Figure caption}

1053 Figure 1. a) Location of all the available studies reporting climate change impacts on 1054 groundwater resources in Eastern Canada (the dotes correspond to the center of the 1055 study area), b) Ontario-based studies, c) Québec-based studies, and d) Atlantic Canada 1056 studies 

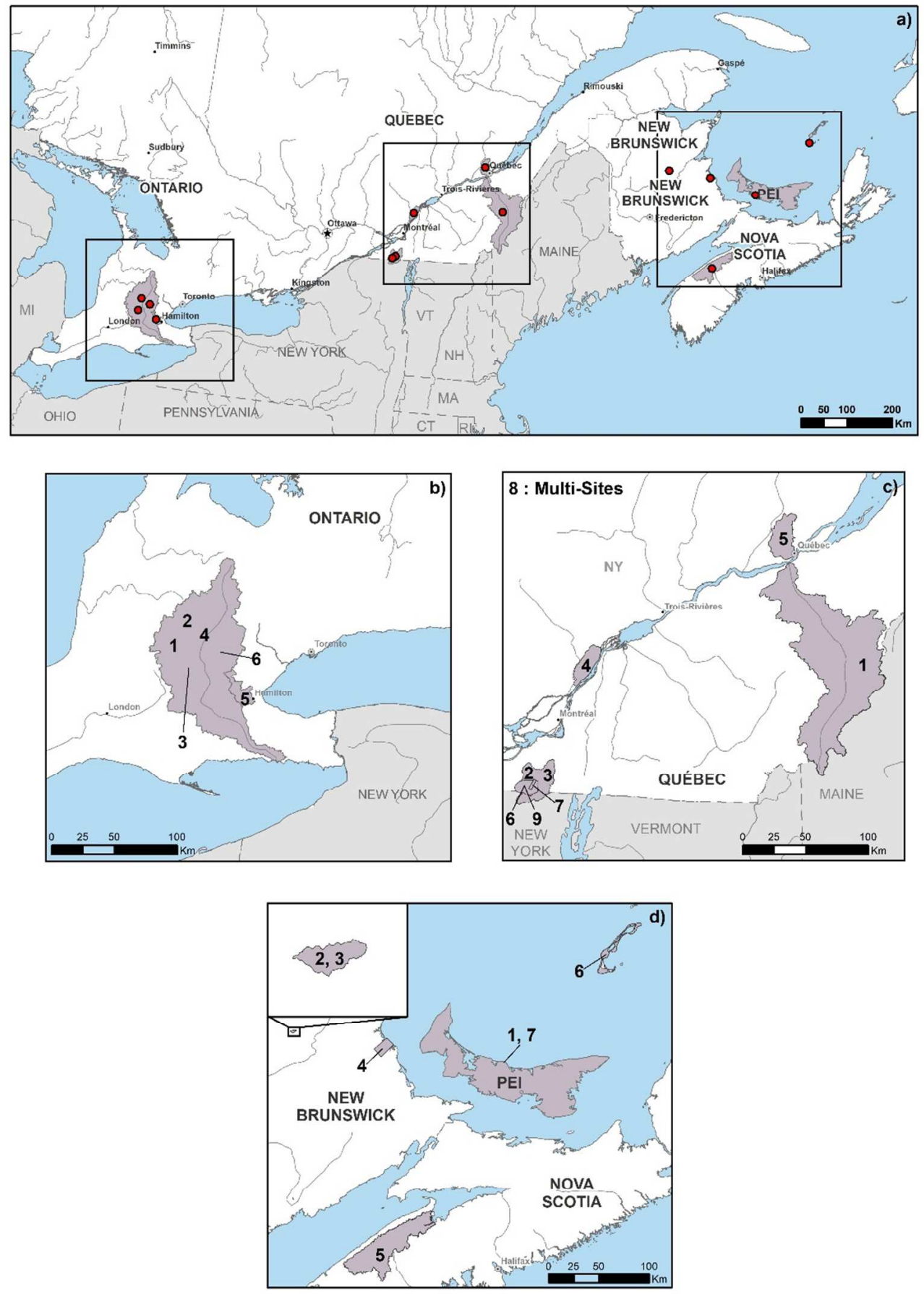

\section{Figure 1}

Larocque et al. 2017

Submitted to Canadian Water Resources Journal 
Table 1. Studies on climate change impacts on groundwater for the Province of Ontario

\begin{tabular}{|c|c|c|c|c|c|c|c|c|}
\hline No. & Study area & Size $\left(\mathrm{km}^{2}\right)$ & Model & Post-processing method(s) & \begin{tabular}{|l} 
Emission \\
scenario(s)
\end{tabular} & \begin{tabular}{|l|} 
Projected \\
horizon(s)
\end{tabular} & $\begin{array}{c}\text { Simulated change in } \\
\text { baseflow }\end{array}$ & $\begin{array}{l}\text { Simulated change in } \\
\text { recharge }\end{array}$ \\
\hline 1. & Subregion of Grand River (ON) & $\begin{array}{l}\text { Not } \\
\text { stated }\end{array}$ & $\begin{array}{l}\text { 2D steady-state } \\
\text { groundwater flow } \\
\text { model }\end{array}$ & Delta change method & $2 \times \mathrm{CO}_{2}$ & 2050 & $-39 \%$ to $-17 \%$ & $-15 \%$ to $+35 \%$ \\
\hline 2. & Grand River (ON) & 6,800 & HELP & Inverse distance squared & $\begin{array}{l}\text { General } \\
\text { predictions from } \\
\text { IPCC (2000) }\end{array}$ & 40 years & n.a. & $+10 \%$ to $+53 \%$ \\
\hline 3. & Alder Creek - Grand River (ON) & 80 & $\begin{array}{l}\text { HELP } \\
\text { HydroSphere }\end{array}$ & Delta change method (monthly) ${ }^{1}$ & $A 2 x, B 2 x$ & $2020-2080$ & n.a. & $+0.36 \mathrm{~mm}$ to $+4.12 \mathrm{~mm}$ \\
\hline 4. & Grand River (ON) & 6,800 & HydroGeoSphere & Perturbed historical records & n.a. ${ }^{2}$ & 40 years & $-15 \%$ to $+59 \%$ & $-5 \%$ to $22 \%$ \\
\hline 5. & Spencer Creek (ON) & 291 & MikeSHE & $\begin{array}{l}\text { Statistical downscaling } \\
\text { Time-lagged-forward neural } \\
\text { networks }\end{array}$ & A2 & $2046-2065$ & n.a. & $-6 \%$ to $-0.5 \%$ \\
\hline 6. & $\begin{array}{l}\text { Guelph region of the Grand } \\
\text { River (ON) }\end{array}$ & $\begin{array}{c}\text { Not } \\
\text { stated }\end{array}$ & HELP & Delta change method (monthly) & n.a. & $2010-2050$ & n.a. & +7 to $+12 \%$ \\
\hline 1. $\mathrm{M}$ & ren and Sudicky (1993) & 3. Bro & uwers (2007) & & & & & \\
\hline
\end{tabular}

${ }^{1}$ Scaling factors were available (monthly) for 2020, 2050 and 2080 and linear interpolation was used between the time slices to distribute monthly scaling factors to a daily timestep. ${ }^{2}$ Synthetic scenarios were constructed based on modifying the $1960-1999$ precipitation record $(-5 \%,+5 \%,+10 \%,+15 \%,+20 \%)$, bounded by GCM-based climate scenarios.

${ }^{3}$ The values are average variations in $\mathrm{mm}$ per month (the minimum is for urban land use and the maximum is for agricultural areas) since the reference values were not provided per land use type by the author for the entire study area.

${ }^{4} \mathrm{~A}$ weather generator algorithm applied changes to a local-climate time series to create future climate conditions. 
Table 2. Studies on climate change impacts on groundwater for the Province of Québec

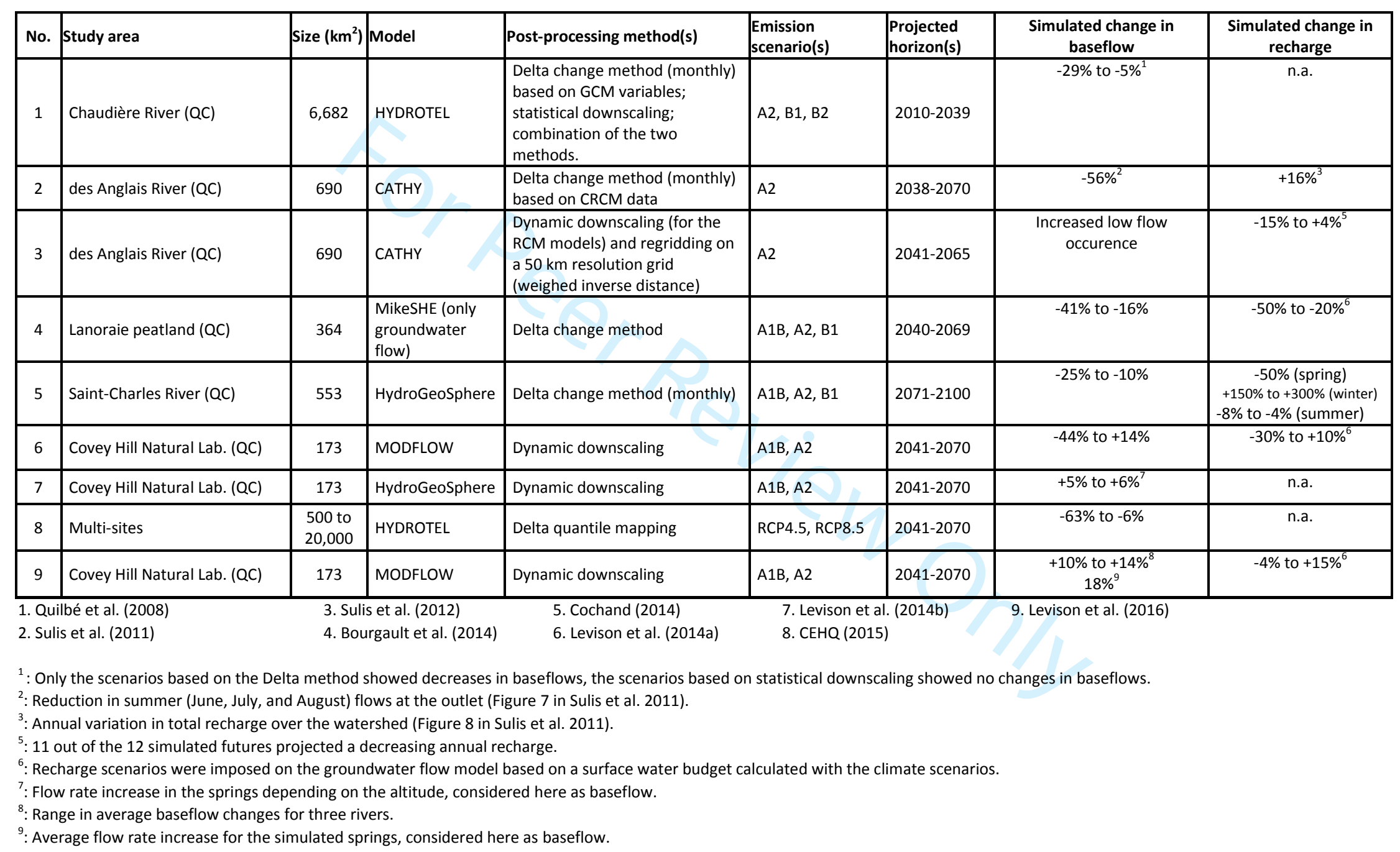


Table 3. Studies on climate change impacts on groundwater for the Atlantic Provinces

\begin{tabular}{|c|c|c|c|c|c|c|c|c|}
\hline No & Study area & Size $\left(\mathrm{km}^{2}\right)$ & Model & Post-processing method(s) & $\begin{array}{l}\text { Emission } \\
\text { scenario(s) }\end{array}$ & $\begin{array}{l}\text { Projected } \\
\text { horizon(s) }\end{array}$ & $\begin{array}{c}\text { Simulated change in } \\
\text { baseflow }\end{array}$ & $\begin{array}{c}\text { Simulated change in } \\
\text { recharge }\end{array}$ \\
\hline 1 & Summerside (PEI) & 4.9 & \begin{tabular}{|l} 
SEAWAT \\
(MODFLOW)
\end{tabular} & Dynamic downscaling & $\begin{array}{l}\text { A1B, A2, B2, } \\
\text { multi-ensemble } \\
\text { approach }\end{array}$ & 2100 & n.a. & $+5 \%$ to $+8 \%^{1}$ \\
\hline 2 & Otter Brook (NB) & 9.5 & HELP & \begin{tabular}{|l|} 
Delta change method (daily), \\
Hybrid multiple regression, and \\
Dynamical downscaling
\end{tabular} & $\mathrm{A} 1 \mathrm{~B}, \mathrm{~A} 2, \mathrm{~B} 1$ & 2046-2065 & n.a. & $-6 \%$ to $+58 \%$ \\
\hline 3 & Otter Brook (NB) & 9.5 & SUTRA & \begin{tabular}{|l} 
Delta change method (daily), \\
Hybrid multiple regression, and \\
Dynamical downscaling \\
\end{tabular} & A1B, A2, B1 & 2046-2065 & $-6 \%$ to $+31 \%^{2}$ & $-6 \%$ to $+58 \%^{3}$ \\
\hline 4 & Richibucto (NB) & 142 & \begin{tabular}{|l} 
HELP \\
SEAWAT \\
(MODFLOW) \\
\end{tabular} & $\begin{array}{l}\text { Mean deviations from climate } \\
\text { indices for 2020s, 2050s and } \\
2080 \text { s calculated }\end{array}$ & A1B, A2 & $2011-2100$ & n.a. & $-27 \%$ to $-5 \%$ \\
\hline 5 & Annapolis Valley (NS) & 546 & HELP & \begin{tabular}{|l|} 
Dynamic downscaling, and \\
Monthly delta method
\end{tabular} & A2 & $2041-2070$ & n.a. & $+14 \%$ to $+45 \%{ }^{4}$ \\
\hline 6 & Magdalen Islands (QC) & 200 & FEFLOW & Delta change method (monthly) & $\mathrm{A} 1 \mathrm{~B}, \mathrm{~A} 2, \mathrm{~B} 1$ & 2013-2040 & $\begin{array}{c}\text { Saltwater-freshwater } \\
\text { interface migrates inland by } \\
37 \mathrm{~m} .\end{array}$ & $-30 \%$ to $0 \%^{5}$ \\
\hline 7 & Prince Edward Island (PEI) & 5,660 & $\begin{array}{l}\text { HELP } \\
\text { FEFLOW }\end{array}$ & Statistical downscaling & $A 2, B 2$ & 2040-2069 & n.a. & $-12 \%$ to $+7 \%$ \\
\hline \multicolumn{2}{|c|}{$\begin{array}{l}\text { 1. Hansen (2012) } \\
\text { 2. Kurylyk and MacQuarrie (2013) }\end{array}$} & \multicolumn{2}{|c|}{ 3. Kurylyk et al. (2014) } & \multicolumn{4}{|c|}{ 5. Rivard et al. (2014) $\quad$ 7. Paradis et al. (2016) } & \\
\hline
\end{tabular}


